\title{
The ichthyofauna of drifting macrophyte mats in the Ivinhema River, upper Paraná River basin, Brazil
}

\author{
Cíntia Karen Bulla ${ }^{1}$, Luiz Carlos Gomes ${ }^{1,2}$, Leandro Esteban Miranda ${ }^{3}$ \\ and Angelo Antonio Agostinho $0^{1,2}$
}

We describe the fish assemblages associated with drifting macrophyte mats and consider their possible role as dispersal vectors in the Ivinhema River, a major tributary of the upper Paraná River, Brazil. Fish associated with drifting mats were sampled in the main river channel during January and March 2005, when the wind and/or the increased water level were sufficient to transport macrophyte stands. Fish in the drifting mats were sampled with a floating sieve ( $4 \mathrm{~m}$ long $\times 2 \mathrm{~m}$ wide $\times 0.6$ $\mathrm{m}$ high, and $2 \mathrm{~mm}$ mesh size). In the laboratory, larvae, juvenile, and adult fish were counted and identified to the lowest possible taxonomic level. In four drifting macrophyte mats we captured 218 individuals belonging to at least 28 species, 17 families, and 6 orders. Aphyocharax dentatus, Serrasalmus spp., and Trachelyopterus galeatus were the most abundant taxa associated with the mats, but species richness ranged from 6 to 24 species per mat. In addition, $85 \%$ of the total number of individuals caught was larvae and juveniles. Although preliminary and based on limited samples, this study of drifting macrophyte mats was the first one in the last unregulated stretch of the Paraná River remaining inside Brazilian territory, and alerts us to the potential role of macrophytes mats as dispersers of fish species in the region.

Nesse trabalho as assembleias de peixes associadas a bancos de macrófitas flutuantes à deriva foram descritas. Além disso, foi considerado o possível papel desses bancos como vetores de dispersão no rio Ivinhema, importante tributário do alto rio Paraná, Brasil. Os peixes associados aos bancos à deriva foram amostrados no canal principal desse rio, entre os meses de Janeiro a Março de 2005, quando o vento e/ou o aumento no nível da água foram suficientes para transportar os bancos de macrófitas. Os peixes foram amostrados com uma rede flutuante $(4 \mathrm{~m}$ de comprimento x $2 \mathrm{~m}$ de largura x $0,6 \mathrm{~m}$ de altura e $2 \mathrm{~mm}$ de tamanho de malha). No laboratório, larvas, jovens e adultos foram contados e identificados ao menor nível taxonômico possível. Nos quatro bancos de macrófitas flutuantes a deriva foram capturados 218 indivíduos pertencentes à pelo menos 28 espécies, 17 famílias e 6 ordens. Aphyocharax dentatus, Serrasalmus spp. e Trachelyopterus galeatus foram os táxons mais abundantes associados aos bancos de macrófitas à deriva, mas a riqueza de espécie variou entre 6 e 24 espécies por banco. Além disso, $85 \%$ do total do número de indivíduos capturados foram larvas e juvenis. Embora preliminar e baseado em amostragens limitadas, este estudo, conduzido em bancos de macrófitas flutuantes à deriva, foi o primeiro no último trecho não regulado do rio Paraná em território brasileiro, e alerta para o papel potencial que os bancos de macrófitas têm como dispersores de peixes na região.

Key words: Dispersion, Fish guilds, Floodplain, Free-floating plants, Freshwater fishes.

${ }^{1}$ Programa de Pós-Graduação em Ecologia de Ambientes Aquáticos Continentais, Universidade Estadual de Maringá. Av. Colombo, 5790, 87020-900 Maringá, Paraná, Brazil.

${ }^{2}$ Departamento de Biologia e Núcleo de Pesquisas em Limnologia, Ictiologia e Aquicultura (Nupélia), Universidade Estadual de Maringá. Av. Colombo, 5790, 87020-900 Maringá, Paraná, Brazil.

${ }^{3}$ Mississippi Cooperative Fish and Wildlife Research Unit, U. S. Geological Survey. P. O. Box 9691, Mississippi State, MS 39762, United States. 


\section{Introduction}

Floodplains are mosaics of biotopes consisting of rivers, side channels, and lakes where the flood pulse is considered the main force that regulates their functioning and that structures their biotic assemblages (Junk et al., 1989; Agostinho et al., 2004). In the littoral areas of these biotopes, there are dense mats of aquatic macrophytes, which are common components of the waterscape (Thomaz et al., 2004) and contribute to increased habitat heterogeneity (Dibble \& Thomaz, 2009; Padial et al., 2009).

Areas covered with macrophytes support high abundances of individuals and species, including fish, due to their role as spawning substrate, refuge against predators, and concentrated food availability (Dibble et al., 1996; Agostinho et al., 2003, 2007; Pelicice et al., 2005). In fact, the presence of macrophytes is essential in the life history of many fish species (Chick \& McIvor, 1997), and some species are associated with patches of dense aquatic vegetation during all stages of their life cycles (Winemiller \& Jepsen, 1998).

During floods, macrophyte stands, especially those composed mainly of free-floating species, frequently fragment and are carried by water flow and/or wind. Thus, fragments detach from littoral areas of floodplain lakes, often forming floating mats, which drift in the main channel of rivers. These mats transport elements of the aquatic fauna, contributing to the dispersal of fish and other organisms in large rivers and lakes (Oliver \& Mckaye, 1982; Sazima \& Zamprogno, 1985; Rossi \& Parma de Croux, 1992; Henderson \& Hamilton, 1995; Horvath \& Lamberti, 1997; Schiesari et al., 2003). However, this dispersal mechanism has received limited study in the Neotropical region and elsewhere, despite its potential importance to the maintenance of local and regional biodiversity. In the intensely regulated Paraná River, these mats will generally reach a reservoir downstream, which is the final destination for the accompanying ichthyofauna.

Considering this gap in knowledge, this study sought to describe the ichthyofauna associated with mats of aquatic macrophytes drifting in a South American rivers. Our goal was to evaluate the possible role of these mats as dispersers of the fish assemblage. Specifically, we aimed to identify fish, according to species as well as trophic and reproductive guilds, drifting in the river within the floating macrophyte mats.

The study was conducted in the Ivinhema River, State of Mato Grosso do Sul, Brazil. With a basin of $38,200 \mathrm{~km}^{2}$, the Ivinhema River is $310 \mathrm{~km}$ long and flows northwest to southeast until it reaches the upper Paraná River floodplain. This floodplain section is $210 \mathrm{~km}$ long and extends from the tailrace of Porto Primavera Dam to the upper reaches of Itaipu Reservoir. Within this floodplain section, the Ivinhema River meanders parallel to the main channel of the Paraná River (Fig. 1). From the Curutuba Channel to the Paraná River, the Ivinhema has a sinuosity quotient of 1.26 , width: depth ratio of $22: 1$, and an average slope of 10.8 $\mathrm{cm} / \mathrm{km}$. In both sides of the river there are several ephemeral and permanent floodplain lakes with some of the largest ones directly connected to the main channel of the river.
The Paraná River has been heavily impounded over the last 40 years. Multiple dams in the mainstem Paraná River and in its tributaries regulate the seasonal hydrological dynamics of the river. Yet, despite a modified hydrograph, the flood pulse is still the main force acting on the aquatic biota of the floodplain section. In addition, depending on the intensity of the flood pulse, mats of aquatic macrophytes are found drifting in the main channel of the Paraná and tributaries, such as the Baia and Ivinhema Rivers, that join the Paraná within the floodplain section. In these rivers, water level rises in November/January to May/June (Agostinho et al., 2001). During these months, it is common to find mats of floating macrophytes drifting in the main channels. Associated with these mats are fish, aquatic invertebrates, amphibians, and organisms that inhabit the submerged and immersed elements of these mats.

Floating macrophyte mats in the Ivinhema River have diverse attributes. They generally include multiple plant species, both free-floating (mainly) and emergent (occasionally).

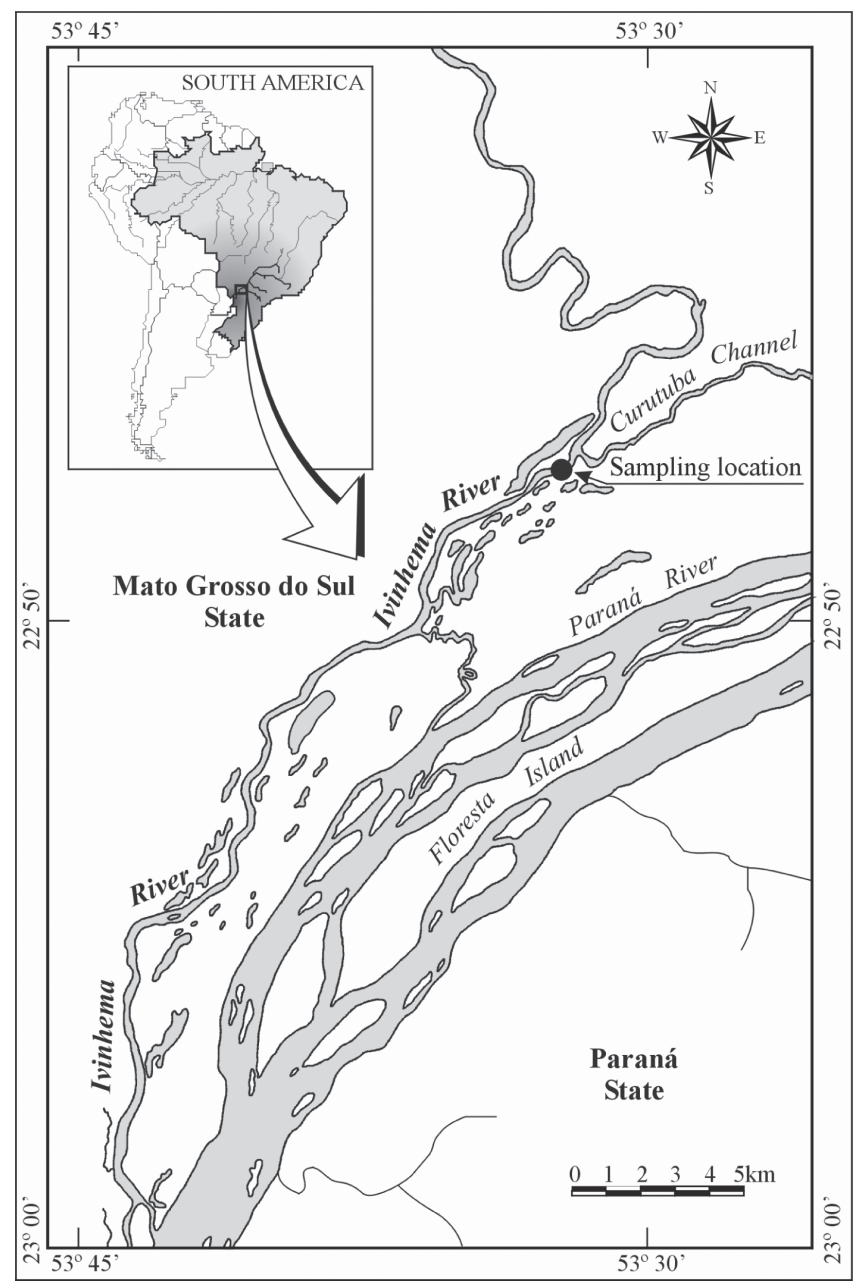

Fig. 1. Map of the floodplain section of the upper Paraná River included in this study, identifying the Ivinhema River and the approximate location where the drifting macrophyte mats were intercepted. 
They originate from fragmented stands of macrophytes formed either in the river during low flow or adjacent floodplain lakes. These mats vary in size, and during intense floods could range up to 1 ha or larger, although they commonly average less than 0.02 ha. Depth of the roots provide additional spatial heterogeneity and depth can range up to about $1 \mathrm{~m}$, but for average size mats depth is generally less than $0.3 \mathrm{~m}$. Small mats often do not drift far because they are easily anchored and disrupted. However, large mats may travel long distances, depending on current velocity, and can reach the Itaipu Reservoir, located $110 \mathrm{~km}$ downstream of the Ivinhema River. Macrophyte mats usually begin drifting in the wet season when water level and velocity increases, although drifting may also be associated with strong wind conditions.

Macrophyte mats were sampled as they drifted in the Ivinhema River in January and March of 2005, between 14:00 and 18:00 h. Sampling was conducted with three boats pulled adjacent to the mat. A floating sieve ( $4 \mathrm{~m}$ long, $2 \mathrm{~m}$ wide, $0.6 \mathrm{~m}$ high, and mesh of $2 \mathrm{~mm}$ stretch/bar measure throughout) was pushed under the floating mat and allowed to surface and accommodate all or part of the mat. Once the sieve was in place, aquatic plants were identified to species level and removed from the sieve. The fish remaining in the sieve were captured, anesthetized in clove oil and stored in plastic bags partially filled with $4 \%$ formalin buffered with calcium bicarbonate.

At a laboratory, fish were identified to the lowest possible taxonomic level. Juveniles and adults were identified based on Graça \& Pavanelli (2007) and larval fish based on Nakatani et al. (2001). Voucher specimens are deposited in the collection of the Núcleo de Pesquisas em Limnologia, Ictiologia e Aquicultura of Universidade Estadual de Maringá (UEM). After identification species were classified into trophic (Hahn et al., 2004) and reproductive (Suzuki et al., 2004) guilds, according to earlier studies conducted in this section of the Paraná River system.

We sampled four macrophyte mats drifting in the Ivinhema River, with average area of $3.9 \mathrm{~m}^{2}$ (Table 1). Three of the mats could be completely engulfed by the sampler; a third mat was bigger but only an area the size of the sampler was assessed. Poor local infrastructure along with strong currents during floods limited our ability to sample more mats. Additionally, sampling mats larger than the sieve sampler were avoided because disconnecting the sieve from the mat would take about $1 \mathrm{~h}$, which created a hazardous situation because the boats drifted freely with the mat, often in strong currents. Macrophytes identified in the mats included Eichhornia azurea, E. crassipes, Hydrocotyle ranunculoides, Polygonum spp., Limnobium laevigatum, Pistia stratiotes, Ricciocarpus natans, Salvinia auriculata, S. herzogii, and S. minima. The predominant macrophytes in two of the mats sampled were Eichhornia crassipes and in the other two mats were Polygonum spp. and Salvinia herzogii.

In all, we captured 218 fish representing 6 orders, 17 families, and at least 28 species (Table 2). Some species have undefined taxonomic status. Additionally, we were not able to identify some individuals to species level (Serrasalmus spp., Serrapinnus spp., Hoplias spp., Hypostomus spp., Pimelodella spp., Characidae, Siluriformes, and Gymnotiformes) due to identification uncertainties related to the stage of development. Serrapinnus spp., Hoplias spp., Hypostomus spp., Characidae, Siluriformes and Gymnotiformes were not counted as species, due to the possibility of double counts. The number of fish collected in each mat was 59, 48, 96 and 15 , for mats $1,2,3$, and 4, respectively (Table 2). On the other hand, the number of species was 12, 9, 24 and 6 , for mats 1,2,3, and 4, respectively (Table 2). We did not discuss these results because differences in the number of individuals and species among mats are difficult to interpret once we did not control for the size of the mats, the size of floodplain lake where it originated, and the distance travelled by the mats.

Orders Characiformes ( 10 species), Siluriformes ( 8 species), and Gymnotiformes ( 6 species) included $86 \%$ of the total taxa collected in the floating mats. Characidae was the most abundant family (46 individuals; $21.1 \%$ of the total), and the family with the highest number of species ( 5 species; $17.8 \%$ ). Auchenipteridae was the second most abundant family (31 individuals), but was represented by a single species, $T$. galeatus. All remaining families (except Loricariidae with three species) were represented by one or two species. The most abundant taxa were $T$. galeatus $(\mathrm{n}=31$; larvae and juveniles), followed by Serrasalmus spp. $(\mathrm{n}=23$; only larvae), and Aphyocharax dentatus $(\mathrm{n}=17$; only juveniles). The only species collected in all four mats were T. galeatus and Crenicichla britskii. The former represented $14.2 \%$ of the total number of individuals collected, whereas the latter included few individuals ( $\mathrm{n}=7$; all juveniles). Larvae and

Table 1. Characteristics of the four floating macrophyte mats sampled while drifting on the Ivinhema River, Brazil, in January and March, 2005. The order of macrophyte species represents numerical dominance.

\begin{tabular}{|c|c|c|c|c|}
\hline \multirow{2}{*}{ Charact eristics } & \multicolumn{4}{|c|}{ Sample number } \\
\hline & 1 & 2 & 3 & 4 \\
\hline Sampling month & January & January & March & March \\
\hline Mat size (length $\mathrm{x}$ width, $\mathrm{m}$ ) & $1.0 \times 1.5$ & $\begin{array}{c}1.5 \times 1.5 \\
\text { E. crassipes }\end{array}$ & $4.0 \times 2.0$ & $2.0 \times 2.0$ \\
\hline Macrop hyte species & $\begin{array}{l}\text { S. herzogii } \\
\text { P. stratiotes } \\
\text { E. azurea } \\
\text { S. minima }\end{array}$ & $\begin{array}{c}\text { P. stratiotes } \\
\text { S. minima } \\
\text { H. ranunculoides } \\
\text { L. laevigatum } \\
\text { R. natans }\end{array}$ & $\begin{array}{c}\text { Polygonum spp. } \\
\text { E. crassipes } \\
\text { S. auriculata }\end{array}$ & $\begin{array}{l}\text { E. crassipes } \\
\text { S. auriculata } \\
\text { S. minima }\end{array}$ \\
\hline
\end{tabular}


Table 2. Number of fish captured in each of the floating macrophyte mats sampled in the Ivinhema River, Mato Grosso do Sul, Brazil (N: total number of individuals of a given species). It is also presented the trophic categories and reproductive guilds (R.G.) of each species. Reproductive guilds are identified as $1=$ long distance migratory species with external fertilization and do not develop parental care; 2 = sedentary or short-distance migratory, external fertilization and no parental care; $3=$ sedentary with external fertilization and parental care; and $4=$ internal fertilization. ${ }^{*}=$ species with few data available in the literature.

\begin{tabular}{|c|c|c|c|c|c|c|c|c|}
\hline \multicolumn{9}{|l|}{ Order } \\
\hline \multirow{2}{*}{$\begin{array}{l}\text { Family (number of species) } \\
\text { Species }\end{array}$} & \multicolumn{5}{|c|}{ Number of fish } & \multirow{2}{*}{$\begin{array}{l}\text { Trophic } \\
\text { cat egory }\end{array}$} & \multirow[b]{2}{*}{ R.G. } & \multirow[b]{2}{*}{ Vouchers } \\
\hline & Mat 1 & Mat 2 & Mat 3 & Mat 4 & $\mathrm{~N}$ & & & \\
\hline \multicolumn{9}{|l|}{ Characiformes } \\
\hline \multicolumn{9}{|l|}{ Anostomidae (2) } \\
\hline Leporinus friderici (B loch, 1794) & 1 & & 1 & & 2 & Omnivore & 2 & NUP 11084 \\
\hline Leporinus lacustris Campos, 1945 & 2 & 2 & 1 & & 5 & Herbivore & 2 & NUP 11110 \\
\hline \multicolumn{9}{|l|}{ Crenuchidae (1) } \\
\hline Characidium aff. zebra Eigenmann, 1909 & 11 & & 5 & & 16 & Invertivore & 2 & NUP 11224 \\
\hline \multicolumn{9}{|l|}{ Characidae (5) } \\
\hline Moenkhausia aff. sanctaefilomenae (Steindachner, 1907) & & & 1 & 1 & 2 & Insectivore & 2 & NUP 11238 \\
\hline Serrasalmus spp. & 17 & & 6 & & 23 & * & 3 & \\
\hline Aphyocharax an isitsi Eigenmann \& Kennedy, 1903 & & & 1 & & 1 & Omnivore* & 2 & NUP 10631 \\
\hline Aphyocharax dentatus Eigenmann \& Kennedy, 1903 & & 11 & 6 & & 17 & Omnivore* & 2 & NUP 11384 \\
\hline Serrapinnus notomelas (Eigenmann, 1915) & & & 1 & & 1 & Algivore* & 2 & NUP 11249 \\
\hline Serrapinnus spp. & & & 2 & & 2 & * & 2 & \\
\hline \multicolumn{9}{|l|}{ Erythrinidae (1) } \\
\hline Hoplias sp. 1 "gnup o malabaricus" & & & 1 & & 1 & Piscivore & 3 & NUP 3456 \\
\hline Hoplias spp. & 2 & & & & 2 & * & 3 & \\
\hline \multicolumn{9}{|l|}{ Lebi asini dae (1) } \\
\hline Pyrrhulina australis Eigen mann \& Kennedy, 1903 & 2 & 3 & & & 5 & Invertivore & 2 & NUP 11587 \\
\hline \multicolumn{9}{|l|}{ Siluri formes } \\
\hline \multicolumn{9}{|l|}{ Cetopsidae (1) } \\
\hline Cetopsis gobioides (Kner, 1858) & & & 1 & & 1 & Invertivore & $2 *$ & \\
\hline Lori cari idae (3) & & & & & & & & \\
\hline Hypostomus ancistroides (Ihering, 1911) & 1 & & 1 & & 2 & Detritivore & 3 & NUP 10547 \\
\hline Hypostomus cf. strigaticeps (Regan, 1908) & & & & 1 & 1 & Detritivore & 3 & NUP11840 \\
\hline Hypostomus sp p. & & 2 & 1 & & 3 & Detritivore & 3 & \\
\hline Pterygoplichthys ambrosettii (Holmberg, 1893 ) & & & 10 & & 10 & Detritivore & 3 & NUP 2115 \\
\hline Hept apteri dae (1) & & & & & & & & \\
\hline Pimelodell a spp. & 1 & & 1 & & 2 & Insectivore & 2 & \\
\hline Doradidae (2) & & & & & & & & \\
\hline Oxydoras eigenmanni (Boulenger, 1895) & & & 15 & & 15 & Invertivore & $2 *$ & \\
\hline Pterodoras granulosus (Val enciennes, 1821) & & & 1 & & 1 & Omnivore & 1 & NUP 1855 \\
\hline Auchenipteri dae (1) & & & & & & & & \\
\hline Tra chelyopterus galeatus (Linnaeus, 1766) & 10 & 13 & 6 & 2 & 31 & Omnivore & 4 & NUP 11104 \\
\hline Gymnotiformes & & & & & & & & \\
\hline Gymnotidae (1) & & & & & & & & \\
\hline Gymnotus inaequilabiatus (Valenciennes, 1839) & 3 & 4 & 3 & & 10 & Insectivore & 3 & NUP 11226 \\
\hline Sternopygidae (2) & & & & & & & & \\
\hline Eigenmannia trilin eata López \& Cast ello, 1966 & & & 7 & & 7 & Insectivore & $2 *$ & NUP 4174 \\
\hline Sternopygus macrurus (Bloch \& Schneider, 1801) & & 5 & 3 & & 8 & Insectivore & $2 *$ & NUP 11216 \\
\hline Rhamphichthyidae (1) & & & & & & & & \\
\hline Gymnorhamphichthys sp. & & & & 7 & 7 & $*$ & & NUP 11515 \\
\hline Apteronotidae (2) & & & & & & & & \\
\hline Apteronotus albifrons (Lin naeus, 1766) & & 3 & 1 & & 4 & Insectivore & $2 *$ & NUP11225 \\
\hline Apteronotus sp. & & & 5 & & 5 & Insectivore* & $2 *$ & \\
\hline Cyprinodonti formes & & & & & & & & \\
\hline Rivulidae (1) & & & & & & & & \\
\hline Rivulus apiamici Costa, 1989 & 3 & 2 & & & 5 & Insectivore* & $2 *$ & NUP 10864 \\
\hline Synbranchiformes & & & & & & & & \\
\hline Synbranchidae (1) & & & & & & & & \\
\hline Synbranchus marmoratus Bloch, 1795 & 2 & & 3 & 1 & 6 & Insectivore & 3 & NUP 4244 \\
\hline $\begin{array}{l}\text { Perciformes } \\
\text { Cichlidae (2) }\end{array}$ & & & & & & & & \\
\hline Astronotus crassipinnis (Heckel, 1840) & & & 1 & & 1 & $\begin{array}{l}\text { Insectivore/ } \\
\text { piscivore }\end{array}$ & 3 & NUP 1464 \\
\hline Crenicichl a britskii Kullander, 1982 & 3 & 1 & 2 & 1 & 7 & Insectivore & 3 & NUP 2355 \\
\hline Larvae not id entified at species level & & & & & & & & \\
\hline Characidae & 1 & 2 & & & 3 & & & \\
\hline Siluriformes & & & 1 & & 1 & & & \\
\hline Gymnotiformes & & & 9 & 2 & 11 & & & \\
\hline Total & 59 & 48 & 96 & 15 & 218 & & & \\
\hline
\end{tabular}


juveniles accounted for $85 \%$ of the collections, and $65 \%$ of the species collected were captured only in these life stages. Nine species were captured as adults only (Aphyocharax anisitsi, Characidium aff. zebra, Gymnorhamphichthys sp., Moenkhausia aff. sanctaefilomenae, Pyrrhulina australis, Rivulus apiamici, Gymnotus inaequilabiatus, Synbranchus marmoratus, and Sternopygus macrurus).

In reference to species guilds representation, insectivores represented the highest number of species collected (11 species), followed by omnivores (5), invertivores (4), and detritivores (4; Table 2). For the reproductive guilds, 12 species were sedentary or short distance migratory, with external fertilization and no parental care. Another 12 species were sedentary or short distance migratory, with external fertilization and parental care. The most abundant species $T$. galeatus was the only which exhibited internal fertilization; and $P$. granulosus (one individual) was the only long distance migratory species collected.

Studies of drifting macrophyte mats are rare in the literature. Oliver \& Mckaye (1982) sampled six wind-drifted mats in Lake Malawi (Malawi-Mozambique-Tanzania) and captured 129 fish of 10 species (average of 22 individuals/mat and 2 species/ mat). Schiesari et al. (2003) captured 286 fish of 39 species in 8 drifting mats in the Solimões River, Central Amazon (average of 36 individuals/mat and 5 species/mat). Henderson \& Hamilton (1995) studied wind-drifted and anchored mats in an Amazonian lake but reported only broad taxa. There are various reasons for the few studies available dealing with this subject, some of which were mentioned by Henderson \& Hamilton (1995). Drifting mats are largely inaccessible because it is difficult to sample under them. If it is possible to net them as we did, it is usually not possible to drag them to shore or dry land for processing. Moreover, the specific environmental conditions needed to set off drifting mats are infrequent and unpredictable, so finding floating mats to sample requires good timing and placing. To better understand drifting macrophyte mats as mechanisms for fauna dispersal, tools to determine drift velocity, pathway, and final destination are needed. Remote sensing (Landsat Images) could improve our ability to monitor drifting mats, and was applied by Petr (2000) to monitor mobility and location of drifting mats in Naivasha Lake, Kenya.

Our collections coincided with the spawning season of most species in the study region (Suzuki et al., 2004). The initial phases of development in fish are critical to the recruitment of new individuals to the stocks, and predation increases the risks of mortality. The greater number of individuals associated with the drifting mats belonged to one species with internal fertilization (e.g., Auchenipteridae) and to several species with parental care (e.g., Gymnotiformes) that usually produce fewer eggs. These species have developed strategies to guard against the high risk of predation. Our study suggests that dispersal within the protection afforded by drifting mats of aquatic macrophytes may be one of these strategies (Sazima \& Zamprogno, 1985; Henderson \& Hamilton, 1995; Schiesari et al., 2003).
Adult fishes also inhabited drifting macrophyte mats. For small sized sedentary species represented by adults $(A$. anisitsi, C. aff. zebra, Gymnorhamphichthys sp., M. aff. sanctaefilomenae, P. australis, and R. apiamici), submerged parts of macrophytes (stems, leaves, and roots) serve as shelter against visual predators and possibly as feeding grounds (Grenouillet \& Pont, 2001; Sánchez-Botero \& AraújoLima, 2001; Casatti et al., 2003; Petry et al., 2003; Pelicice et al., 2005; Padial et al., 2009). Insects and other aquatic invertebrates are commonly found attached to roots and leaves of aquatic plants, and potentially may serve as food for most fish species associated to these plants (Neiff \& Carignan, 1997; Padial et al., 2009). Moreover, Rossi \& Parma de Croux (1992) report that macrophytes can be directly used as food and, additionally, contribute to the production of detritus and may serve as substrate to the colonization of periphyton. All these aspects may be contributing to the predominance of certain trophic groups (i.e., insectivores, omnivores, invertivores, and detritivores) in the macrophyte mats analyzed. While these species may be attracted to mats for shelter and food, or are unintended travelers, the mats provide these species relatively rapid dispersal vectors.

In contrast, for G. inaequilabiatus, S. macrurus, and $S$. marmoratus for which larvae, juveniles, and adults were collected in the drifting mats, macrophyte stands seem to be a habitat used during all life stages. Presence of all life stages indicates the close relation of the life strategy of these species with aquatic vegetation, confirmed by species characteristics such as sedentary habit, elongated and thin body, insectivory, cryptic coloration, and adaptations to thrive in low dissolved oxygen concentration. The family Synbranchidae and the Gymnotiformes (including the three aforementioned species) have adaptations to inhabit macrophyte stands (MachadoAllison, 1993; Henderson \& Hamilton, 1995; Crampton \& Hopkins, 2005). However, Henderson \& Hamilton (1995) reported that Synbranchidae, Gymnotiformes, and Erythrinidae avoided drifting mats and preferred the anchored stands in the margins of the Amazonian plain. They report that these groups are capable of sensing the changes related to detachment of the stands and will flee floating mats towards anchored stands. Our results contradict their observations as we captured all life stages drifting in mats. On the other hand, in our study, we collected few individuals of long distance migratory species in this type of habitat, which may be an indication that they do not stay in floating mats.

A surprising finding was the collection of several fish species considered uncommon in the region. For example, Apteronotus sp. and Gymnorhamphichthys sp. are considered rare as they are seldom collected in other habitats or by other gear (Graça \& Pavanelli, 2007). Other infrequent species in standard surveys conducted in the region include $A$. albifrons, R. apiamici, and C. gobioides (Agostinho et al., 2005 ) that were captured in the macrophyte mats sampled. Thus, while floating macrophyte mats represent an ephemeral habitat type, they do appear to attract a unique set of species and life stages. 
The high abundance of Serrasalmus spp. larvae in the drifting mats may be due its reproductive strategy. According to Machado-Allison (1993), Serrasalmus spp. lay eggs in the marginal vegetation, with larvae and initial phases of development strongly associated to this environment. After attaining certain size, they move to explore open water, displaying ontogenetic variations in habitat use. Sazima \& Zamprogno (1985) studied the Atibaia River (Tietê River upper Paraná River basin) and suggested that macrophyte stands serve as shelter and are rich feeding places for larvae and juveniles of Serrasalmus spilopleura (nowadays Serrasalmus maculatus). In addition, they report that drifting macrophyte mats disperse this species, explaining its wide distribution. Thus, the high synchronization between the drift of the mats and the spawning season of this species (Schiesari et al., 2003) may favor the establishment of viable populations at a regional scale.

The same pattern may apply to T. galeatus in the upper Paraná River. This species has internal fertilization and lay eggs in macrophyte roots, where early developmental stages also stay in macrophytes until later stages. This mechanism may be important regionally because below the upper Paraná River floodplain section there is the Itaipu Reservoir, where Serrasalmus spp. are common (Hahn et al., 1998; Oliveira et al., 2005), explained by its preference for lentic environs. However, the high abundance of species with internal fertilization in this reservoir, such as the siluriform T. galeatus, is unexplained (Agostinho et al., 1999) and possibly attributed to drifting macrophyte mats, once density of floating aquatic macrophytes (the habitat considered in this study) in this reservoir is low (Thomaz et al., 2006), with dominance of submerged species (Thomaz et al., 1999). In fact, Henderson \& Hamilton (1995) reported that siluriforms favored drifting mats over anchored stands, and concluded that for this group the downstream drift may represent a seasonal migration to the main river channel. Thus, these authors consider the possibility of a life strategy related to dispersal through drifting under the safety and sustenance of drifting macrophyte stands.

Macrophyte stands in the upper Paraná River basin support several fish species (at least 28 species in four mats) and the underwater parts of these plants provide shelter and forage for all life stages of fish. Although preliminary and based on limited samples, this study of drifting macrophyte mats was the first one in the last unregulated stretch of the Paraná River remaining inside Brazilian territory, and alerts us to their potential role as dispersers of fish species in the region. Constant or sporadic dispersion through this mechanism may maintain genetic flow among metapopulations, reducing isolation and favoring the homogeneity of the biota, locally or regionally. However, more studies are needed to clearly determine utilization by key species and guilds. Additional studies will contribute to understanding if movements of fish through drifting macrophyte mats are simply random or a dispersal life strategy used by segments of the fish community.

\section{Acknowledgements}

We are grateful to Nupélia for providing the infrastructure to collect data. This project was developed within the Brazilian Long Term Ecological Research, Site 6, conducted in the upper Paraná River floodplain. João Dirço Latini coordinated the entire operation in field. CKB was supported by CAPES; LCG and AAA are Productivity Researchers of CNPq.

\section{Literature Cited}

Agostinho, A. A., L. C. Gomes \& H. F. Júlio Jr. 2003. Relações entre macrófitas e fauna de peixes. Pp. 261-279. In: Thomaz, S. M. \& L. M. Bini (Eds.). Ecologia e manejo de macrófitas aquáticas. Maringá, Eduem, 341p.

Agostinho, A. A., L. C. Gomes, S. M. Thomaz \& N. S. Hahn. 2004. The upper Paraná River and its floodplain: main characteristics and perspectives for management and conservation. Pp. 381-393. In: Thomaz, S. M., A. A. Agostinho \& N. S. Hahn (Eds.). The Upper Paraná River and its Floodplain: Physical aspects, Ecology and Conservation. Leiden, the Netherlands: Backhuys Publishers, 399p.

Agostinho, A. A., L. C. Gomes \& M. Zalewski. 2001. The importance of floodplains for the dynamics of fish communities of the upper Paraná River. International Journal of Ecohydrology \& Hydrobiology, 1: 209-217.

Agostinho, A. A., L. E. Miranda, L. M. Bini, L. C. Gomes, S. M. Thomaz \& H. I. Suzuki. 1999. Patterns of colonization in neotropical reservoirs, and prognoses on aging. Pp. 227-265. In: Tundisi, J. G., M. Straskraba (Eds.). Theoretical Reservoir Ecology and its applications. São Carlos-SP: IIE/Backhuys Publishers/Brazilian Academy of Sciences, 592p.

Agostinho, A. A., F. M. Pelicice \& H. F. Júlio Jr. 2005. Introdução de espécies de peixes em águas continentais brasileiras: uma síntese. Pp. 13-23. In: Rocha, O., E. L. G. Espíndola, N. Fenerich-Verani, J. R. Verani \& A. C. Rietzler (Eds.). Espécies invasoras em águas doces: estudos de caso e propostas de manejo. 1 Ed. São CarlosSP: Editora Universidade Federal de São Carlos, 416p.

Agostinho, A. A., S. M. Thomaz, L. C. Gomes \& S. L. S. M. A. Baltar. 2007. Influence of Eichhornia azurea on fish Assemblages of the Upper Paraná River Floodplain (Brazil). Aquatic Ecology, 41: 611-619.

Casatti, L., H. F. Mendes \& K. M. Ferreira. 2003. Aquatic macrophytes as feeding site for small fishes in the Rosana reservoir, Paranapanema River, southeastern Brazil. Brazilian Journal of Biology, 63: 213-222.

Chick, J. H. \& C. C. McIvor. 1997. Habitat selection by three littoral zone fishes: effects of predation pressure, plant density and macrophyte type. Ecology of Freshwater Fish, 6: 27-35.

Crampton, W. G. R. \& C. D. Hopkins. 2005. Nesting and paternal care in the weakly electric fish Gymnotus (Gymnotiformes: Gymnotidae) with descriptions of larval and adult electric organs discharges of two species. Copeia, 2005: 48-60.

Dibble, E. D., K. J. Killgore, S. L. Harrel. 1996. Assessment of fishplant interactions. Pp. 357-372. In: Miranda, L. E. \& D. R. Devries (Eds.). Multidimensional approaches to reservoir fisheries management. Bethesda, Maryland: American Fisheries Society Symposium 16, 463p.

Dibble, E. D. \& S. M. Thomaz. 2009. Use of fractal dimension to assess habitat complexity and its influence on dominant invertebrates inhabiting tropical and temperate macrophytes. Journal of Freshwater Ecology, 24: 93-102. 
Graça, W. J. \& C. S. Pavanelli. 1997. Peixes da planície de inundação do alto rio Paraná e áreas adjacentes. Maringá, Eduem, 241p.

Grenouillet, G. \& D. Pont. 2001. Juvenile fishes in macrophyte beds: influence of food resources, habitat structure and body size. Journal of Fish Biology, 59: 939-959.

Hahn, N. S., A. A. Agostinho, L. C. Gomes \& L. M. Bini. 1998. Estrutura trófica da ictiofauna do Reservatório de Itaipu (ParanáBrasil) nos primeiros anos de sua formação. Interciência, 23: 299-305.

Hahn, N. S., R. Fugi \& I. F. Andrian. 2004. Trophic Ecology of Fish Assemblages. Pp. 381-393. In: Thomaz, S. M., A. A. Agostinho \& N. S. Hahn (Eds.). The Upper Paraná River and its Floodplain: Physical aspects, Ecology and Conservation. Leiden, the Netherlands: Backhuys Publishers, 399p.

Henderson, P. A. \& H. F. Hamilton. 1995. Standing crop and distribution of fish in drifting and attached floating meadow within an Upper Amazonian varzea lake. Journal of Fish Biology, 47: 266-276.

Horvath, T. G. \& G. A. Lamberti. 1997. Drifting macrophytes as a mechanism for zebra mussel (Dreissena polymorpha) invasion of lake-outlet streams. American Midland Naturalist, 138: 2936.

Junk, W. J., P. B. Bayley \& R. E. Sparks. 1989. The flood pulse concept in river-floodplain systems. Canadian Special Publication of Fisheries and Aquatic Sciences, 106: 110-127.

Machado-Allison, A. 1993. Los peces de los llanos de Venezuela: un ensayo sobre su historia natural. Caracas: Universidad Central de Venezuela, Consejo de Desarrollo Científico y Humanístico, 143p.

Nakatani, K., A. A. Agostinho, G. Baumgartner, A. Bialeztki, P. V. Sanches, M. C. Makrakis \& C. S. Pavanelli. 2001. Ovos e larvas de peixes de água doce: desenvolvimento e manual de identificação. Maringá, Eduem, 378p.

Neiff, A. P. \& R. Carignan. 1997. Macroinvertebrates on Eichhornia crassipes roots in two lakes of the Paraná River floodplain. Hydrobiologia, 345: 185-196.

Oliveira, E. F., C. V. Minte-Vera \& E. Goulart. 2005. Structure of fish assemblages along spatial gradients in a deep subtropical reservoir (Itaipu Reservoir, Brazil-Paraguay border). Environmental Biology of Fish, 72: 283-304.

Oliver, M. K. \& K. R. Mckaye. 1982. Floating islands: a means of fish dispersal in Lake Malawi, Africa. Copeia, 1982: 748-754.

Padial, A. A., S. M. Thomaz \& A. A. Agostinho. 2009. Effects of structural heterogeneity provided by the floating macrophyte Eichhornia azurea on the predation efficiency and habitat use of the small Neotropical fish Moenkhausia sanctaefilomenae. Hydrobiologia, 624: 161-170.
Pelicice, F. M., A. A. Agostinho \& S. M. Thomaz. 2005. Fish assemblages associated with Egeria in a tropical reservoir: investigating the effects of plant biomass and diel period. Acta Oecologica, 27: 9-16.

Petr, T. 2000. Interactions between fish and aquatic macrophytes in inland waters: a review. FAO Fisheries Technical Paper 396, $185 \mathrm{p}$.

Petry, P., P. B. Bayley \& D. F. Markle. 2003. Relationships between fish assemblages, macrophytes and environmental gradients in the Amazon River Floodplain. Journal of Fish Biology, 63: 547579.

Rossi, L. M. \& M. J. Parma de Croux. 1992. Influencia de la vegetación acuática en la distribución de peces del río Paraná, Argentina. Ambiente Subtropical, 2: 65-75.

Sánchez-Botero, J. I. \& C. A. R. M. Araújo-Lima. 2001. As macrófitas aquáticas como berçário para a ictiofauna da várzea do rio Amazonas. Acta Amazônica, 31: 437-447.

Sazima, I. \& C. Zamprogno. 1985. Use of water hyacinths as shelter, foraging place, and transport by young piranhas, Serrasalmus spilopleura. Environmental Biology of Fishes, 12: 237-240.

Schiesari, L., J. Zuanon, C. Azevedo-Ramos, M. Garcia, M. Gordo, M. Messias \& E. M. Vieira. 2003. Macrophyte rafts as dispersal vectors for fishes and amphibians in the Lower Solimões River, Central Amazon. Journal of Tropical Ecology, 19: 333-336.

Suzuki, H. I., A. E. A. M. Vazzoler, E. E. Marques, M. A. P. Lizama \& P. Inada. 2004. Reproductive Ecology of the Fish Assemblages. Pp. 381-393. In: Thomaz, S. M., A. A. Agostinho \& N. S. Hahn (Eds.). The Upper Paraná River and its Floodplain: Physical aspects, Ecology and Conservation. Leiden, the Netherlands: Backhuys Publishers, 399p.

Thomaz, S. M., L. M. Bini, T. A. Pagioro, K. J. Murphy, A. M. Santos \& D. C. Souza. 2004. Aquatic macrophytes: diversity, biomass and decomposition. Pp. 617-625. In: Thomaz, S. M., A. A. Agostinho \& N. S. Hahn (Eds.). The Upper Paraná River and its Floodplain: Physical aspects, Ecology and Conservation. Leiden, the Netherlands: Backhuys Publishers, 399p.

Thomaz, S. M., L. M. Bini, M. C. Souza, K. K. Kita \& A. F. M. Camargo. 1999. Aquatic macrophytes of Itaipu Reservoir, Brazil: Survey of species and ecological considerations. Brazilian Archives of Biology and Technology, 42: 15-22.

Thomaz, S. M., T. A. Pagioro, L. M. Bini \& K. J. Murphy. 2006. Effect of reservoir drawdown on biomass of three species of aquatic macrophytes in a large sub-tropical reservoir (Itaipu, Brazil). Hydrobiologia, 570: 53-59.

Winemiller, K. O. \& D. B. Jepsen. 1998. Effects of seasonality and fish movement on tropical river food webs. Journal of Fish Biology, 53(suppl. A): 267-296. 